University of Wollongong

Research Online

Faculty of Engineering - Papers (Archive)

Faculty of Engineering and Information

Sciences

$1-7-2006$

\title{
Laboratory Evaluation of Smear Zone and Correlation between Permeability and Moisture Content
}

I. Sathananthan

University of Wollongong

B. Indraratna

University of Wollongong, indra@uow.edu.au

Follow this and additional works at: https://ro.uow.edu.au/engpapers

Part of the Engineering Commons

https://ro.uow.edu.au/engpapers/105

\section{Recommended Citation}

Sathananthan, I. and Indraratna, B.: Laboratory Evaluation of Smear Zone and Correlation between

Permeability and Moisture Content 2006.

https://ro.uow.edu.au/engpapers/105

Research Online is the open access institutional repository for the University of Wollongong. For further information contact the UOW Library: research-pubs@uow.edu.au 


\title{
Laboratory Evaluation of Smear Zone and Correlation between Permeability and Moisture Content
}

\author{
Iyathurai Sathananthan ${ }^{1}$ and Buddhima Indraratna, F.ASCE ${ }^{2}$
}

\begin{abstract}
In this study, the extent of the smear zone and the reduction of permeability and water content within the smear zone were investigated using a large-scale consolidometer. The installation of vertical drains by means of a mandrel causes significant disturbance of the subsoil surrounding the mandrel, resulting in a smear zone. The extent of the smear zone for Moruya clay (New South Wales, Australia) was estimated on the basis of normalized permeability and the reduction of water content by taking undisturbed samples (horizontally and vertically) at different locations. This study reveals that a significant reduction in water content and horizontal permeability takes place towards the drain, whereas the variation in the vertical permeability is negligible. The smear zone for Moruya clay was found to be 2.5 times the equivalent radius of the mandrel with the horizontal permeability varying from 1.09 to 1.64 , an average of 1.34 times smaller than that of the undisturbed zone. Finally, a correlation between the permeability decrease and water content reduction within smear zone is proposed.
\end{abstract}

DOI: 10.1061/(ASCE)1090-0241(2006)132:7(942)

CE Database subject headings: Clays; Laboratory tests; Water content; Permeability.

\section{Introduction}

Even though there are a variety of soil improvement techniques available to stabilize the soft ground, the application of preloading with prefabricated vertical drains is still regarded as one of the classical and popular methods in practice. Nevertheless, the installation of vertical drains in the field causes significant remolding of the subsoil, especially in the immediate vicinity of the mandrel. The resulting smear zone will have reduced lateral permeability, which adversely affects soil consolidation.

The combined effect of permeability and compressibility within the smear zone causes a different behavior from the undisturbed soil. Predicting soil behavior surrounding the drain requires an accurate estimation of the smear zone properties. Classical solutions (Barron 1948; Hansbo 1981; Indraratna and Redana 1997) have considered the influence of the smear zone with an idealized two-zone model, where the smear zone is the disturbed region in the immediate vicinity of the drain, and the outer zone is the intact (undisturbed) region.

The writers propose that the key parameters necessary to characterize the smear effect are the smear zone diameter $\left(d_{s}\right)$ and the normalized lateral permeability $\left(k_{h} / k_{h u}\right)$, i.e., the coefficient of lateral permeability $\left(k_{h}\right)$ over the maximum lateral permeability

${ }^{1}$ Ph.D. Candidate, Faculty of Engineering, Univ. of Wollongong, Wollongong City, NSW 2522, Australia.

${ }^{2}$ Professor of Civil Engineering, School of Civil Engineering, Univ. of Wollongong, Wollongong City, NSW 2522, Australia (corresponding author). E-mail: indra@uow.edu.au

Note. Discussion open until December 1, 2006. Separate discussions must be submitted for individual papers. To extend the closing date by one month, a written request must be filed with the ASCE Managing Editor. The manuscript for this technical note was submitted for review and possible publication on March 21, 2005; approved on December 7, 2005. This technical note is part of the Journal of Geotechnical and Geoenvironmental Engineering, Vol. 132, No. 7, July 1, 2006. (CASCE, ISSN 1090-0241/2006/7-942-945/\$25.00. of the undisturbed zone $\left(k_{h u}\right)$. Both the smear zone diameter and its permeability are often difficult to quantify and determine from laboratory tests. So far, there is no comprehensive or standard method for measuring them. Indraratna and Redana (1998) proposed that the estimated smear zone $\left(d_{s}\right)$ could be as large as 4 to 5 times equivalent drain diameter $\left(d_{w}\right)$ and that the horizontal to vertical permeability ratio $\left(k_{h} / k_{v}\right)$ is close to unity in the smear zone. This was verified using a specially designed large-scale consolidometer. In the Indraratna and Redana (1998) approach, the vertical permeability was shown to be relatively unaffected by mandrel installation. Therefore in the current analysis the normalized lateral permeability $\left(k_{h} / k_{h u}\right)$ was taken to be more realistic than the $k_{h} / k_{v}$ ratio in determining the effect of smear. In the current research, an attempt is made to characterize the smear zone, based on permeability and water content measurements, using large-scale laboratory tests.

\section{Experimental Setup and Testing Procedure}

The large-scale radial drainage consolidometer cell consists of two cylindrical (stainless steel) half sections, each of which has a flange running the length of the cylinder so that they can be bolted together. The cell dimensions are $650 \mathrm{~mm}$ internal diameter $\times 1,040 \mathrm{~mm}$ height $\times 8 \mathrm{~mm}$ thick, and it has a $1.5 \mathrm{~mm}$ thick Teflon sleeve fitted around the internal cell boundary to reduce friction. The bolted cell (Fig. 1) is mounted on a steel base. The loading can be applied by an air jack compressor system via a piston. An LVDT (linear variable differential transformer) transducer is placed on top of the piston to monitor surface settlement, and pore pressure transducers are also installed to measure the excess pore water pressures at various depths.

The main steps involved in the test are the preparation of clay deposit, installation of the prefabricated vertical drain (PVD), and the collection of samples at the end of consolidation to measure the permeability and water content. Given the dimensions of the large cell, it was almost impossible to obtain undisturbed samples 


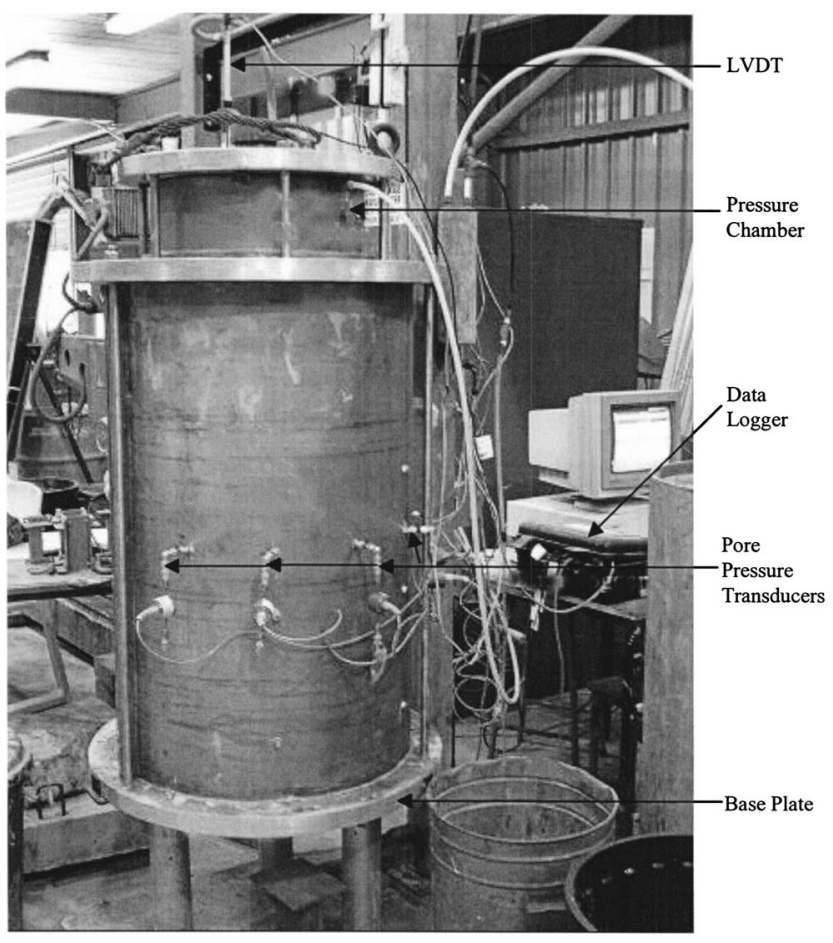

Fig. 1. Large-scale radial drainage consolidometer

of this size. Therefore commercially available reconstituted alluvial Moruya clay was used to prepare the samples.

First, the clay was thoroughly mixed with water and kept in a closed container for several days to ensure full saturation. Then the cell was filled with the prepared reconstituted clay in $150 \mathrm{~mm}$ layers by compacting or vibrating to expel any trapped air before adding the next layer, to a total height of $950 \mathrm{~mm}$. To ensure that the clay was fully saturated, a couple of small cylindrical specimens $(38 \mathrm{~mm} \times 76 \mathrm{~mm})$ were cored and tested in the triaxial equipment. Skempton's $B$ parameter of 0.99 or more was determined. After specimen preparation, a layer of filter cloth was placed on top of the clay followed by the top plate. Subsequently, the load cell was installed on top of the plate to measure the applied load from the pressure chamber. An initial preconsolidation pressure of $20 \mathrm{kPa}$ was applied prior to drain installation.

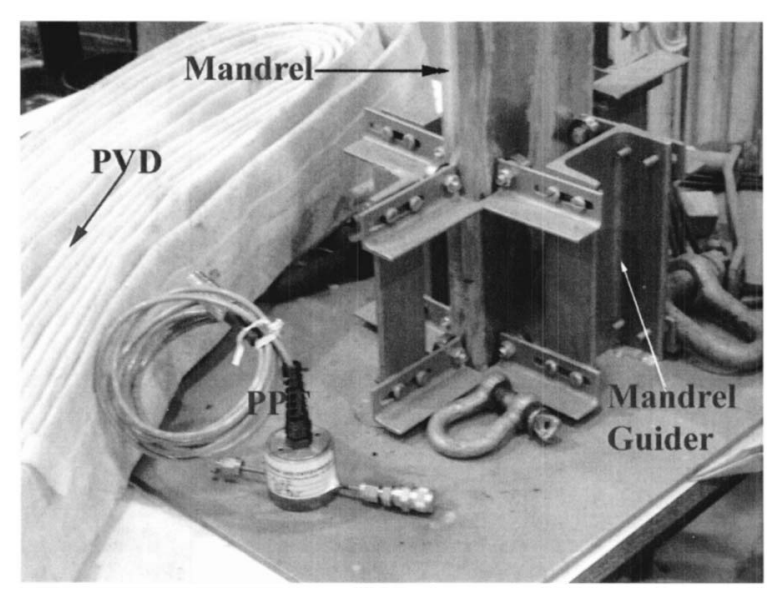

Fig. 2. Mandrel, guider, and pore pressure transducer assembly

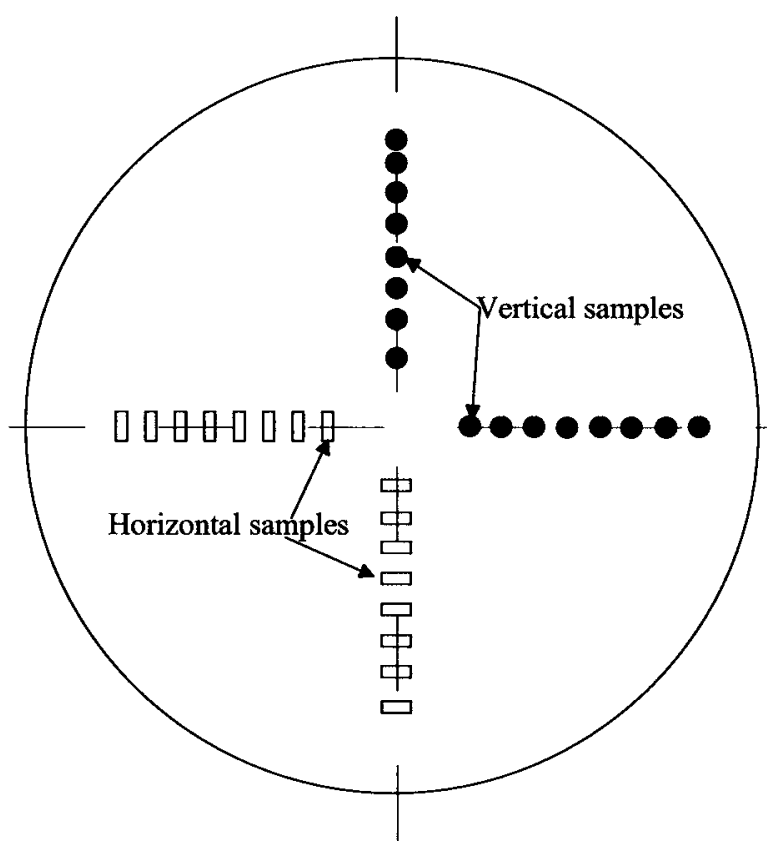

Fig. 3. Location of cored samples

A single prefabricated vertical band drain $(100 \mathrm{~mm} \times 3 \mathrm{~mm})$ was installed at a rate of $0.5 \mathrm{~m} / \mathrm{min}$ using a specially designed $125 \mathrm{~mm} \times 25 \mathrm{~mm}$ rectangular mandrel (Fig. 2). The mandrel radius based on the equivalent area $\left(r_{m}\right)$ is $31.5 \mathrm{~mm}$. The end of the drain was attached to a "shoe" to ensure the drain remained anchored in the predetermined depth $(0.95 \mathrm{~m}$ from the surface) when the mandrel was withdrawn. The consolidation pressure was applied in stages up to a maximum of $200 \mathrm{kPa}$. Finally, at the completion of consolidation, 32 soil samples were collected at different vertical and radial locations (Fig. 3) to determine the permeability and water content using the standard oedometer test. The detailed testing procedure is explained elsewhere by Indraratna and Redana (1998).

\section{Presentation of Test Results and Analysis}

\section{Prediction of Smear Zone from Permeability Measurements}

At the end of the large-scale consolidation test, horizontal and vertical samples were cored at $0.5 \mathrm{~m}$ below the surface. Variations of the horizontal and vertical coefficient of permeability $\left(k_{h}\right.$ and $\left.k_{v}\right)$, the permeability ratios $\left(k_{h} / k_{v}\right)$, and the normalized lateral permeability $\left(k_{h} / k_{h u}\right)$ for different mean applied consolidation pressures are plotted in Fig. 4.

Fig. 4(a) shows that towards the drain, the horizontal permeability decreases significantly within a certain radial distance, whereas Fig. 4(b) shows that the variation in vertical permeability with radial distance is marginal. This indicates that the mandrel installation mainly affects the horizontal (lateral) permeability, which can be explained by cylindrical cavity expansion with accompanying lateral (radial) soil compaction. The permeability anisotropy is shown in Fig. 4(c), which clearly demonstrates the reduction of $k_{h} / k_{v}$ ratios in the smear zone. In contrast, Fig. 4(d) shows the normalized lateral permeability $\left(k_{h} / k_{h u}\right)$. It is of interest to note that irrespective of the applied pressure, all plots are confined within a narrow band, clearly defining the extent of the 


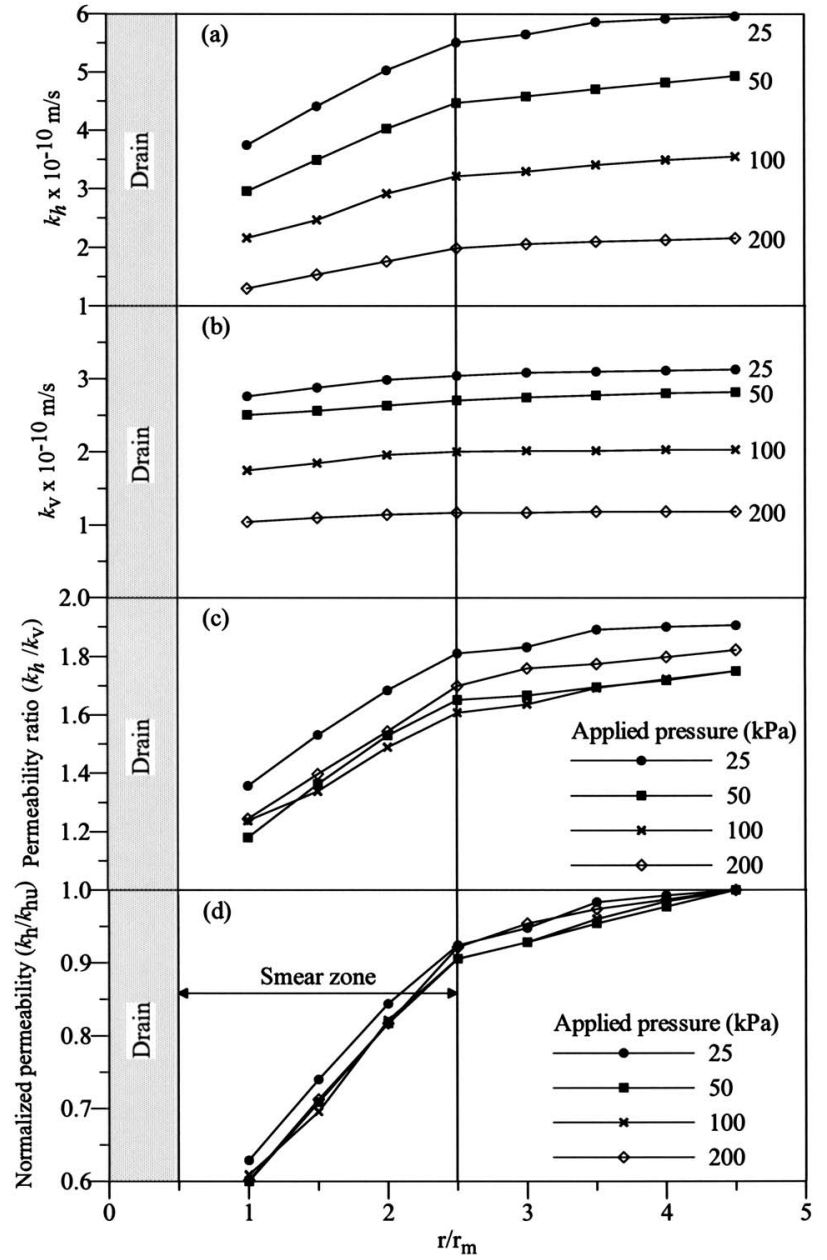

Fig. 4. Variation of (a) horizontal permeability; (b) vertical permeability; (c) permeability ratio; and (d) normalized lateral permeability, with radial distance

smear zone. From these data, one may conclude that the smear zone is about 2.5 times the equivalent mandrel radius $\left(r_{m}\right)$, and that the normalized lateral permeability in the smear zone varies between 1.09 and 1.64 with an average of 1.34. Moreover, very close to the drain, the $k_{h} / k_{v}$ ratio is expected to approach unity, where the soil remolding is maximum.

\section{Prediction of Smear Zone from Reduction of Water Content}

Various researchers (e.g., Taylor 1948; Samarasinghe et al. 1982; Tavenas et al. 1983a; b; Babu et al. 1993) have discussed the effect of void ratio on the permeability. They have concluded that permeability is dependent upon the void ratio and the water content of the soil. In this research, an attempt is made to examine the extent of the smear zone from the variation of water content and the normalized water content reduction, i.e., $\left(w_{\max }-w\right) / w_{\max }$. For this purpose, samples were collected at five vertical and eight radial locations. The variation of the water content and the normalized water content reduction with radial distance at a depth of $0.5 \mathrm{~m}$ is illustrated in Fig. 5. The variation of water content [Fig. 5(a)] shows a similar trend to the variation of $k_{h}$ as shown previously in Fig. 4(a). The normalized water content reduction is plotted in Fig. 5(b), which shows that all data are confined within a narrow band, again demarcating the smear zone. The variation

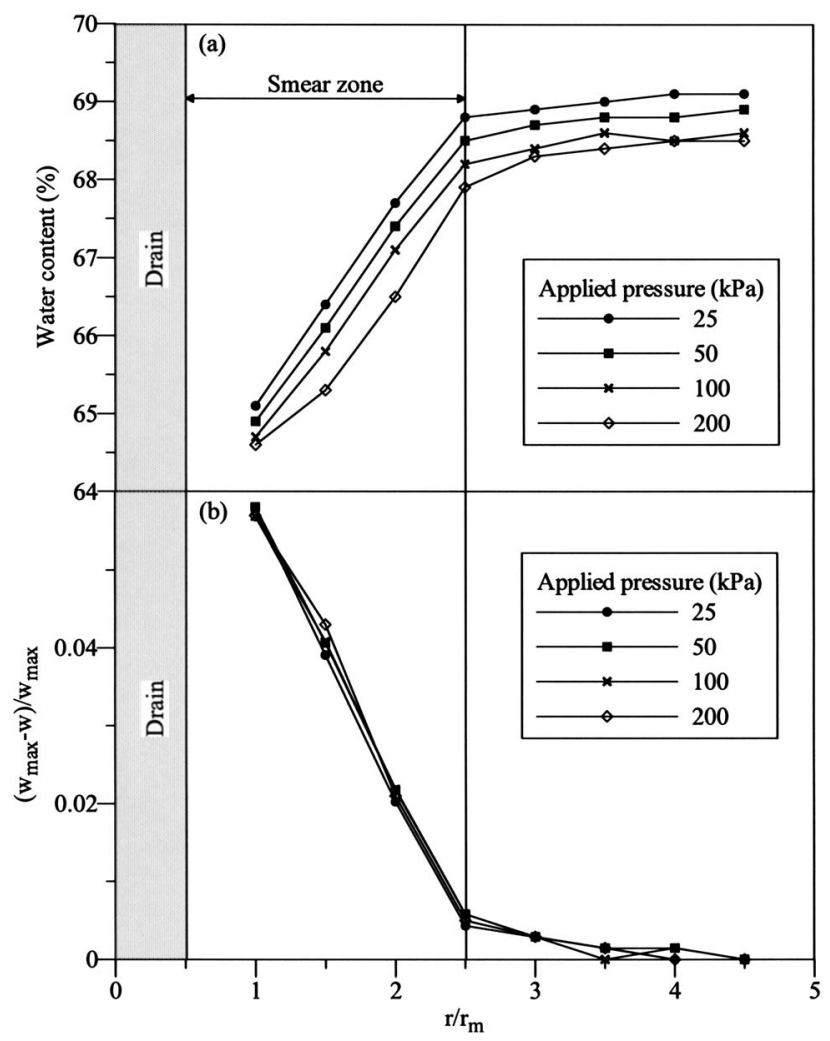

Fig. 5. Variation of (a) water content; (b) normalized water content reduction with radial distance at a depth of $0.5 \mathrm{~m}$

of the water content with depth and radial distance is shown in Fig. 6 for an applied pressure of $200 \mathrm{kPa}$. As expected, the water content decreases towards the drain, and also the water content is greater towards the bottom of the cell at all radial locations. Based on these curves, the extent of smear zone can be estimated to be around 2.5 times the equivalent mandrel radius. This agrees well with the estimated extent of smear zone based on both the $k_{h} / k_{v}$ ratio [Fig. $\left.4(\mathrm{c})\right]$ and the $k_{h} / k_{h u}$ ratio [Fig. $4(\mathrm{~d})$ ].

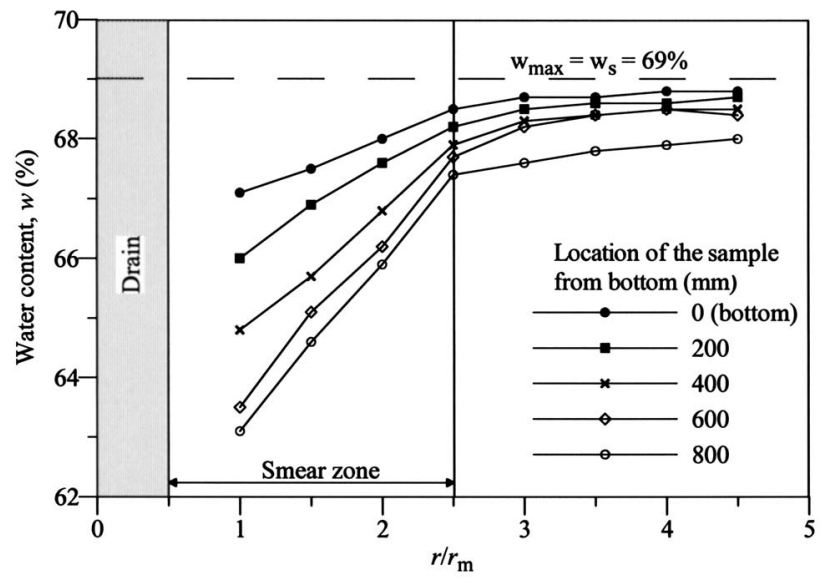

Fig. 6. Variation of water content with depth and radial distance for an applied pressure of $200 \mathrm{kPa}$ 


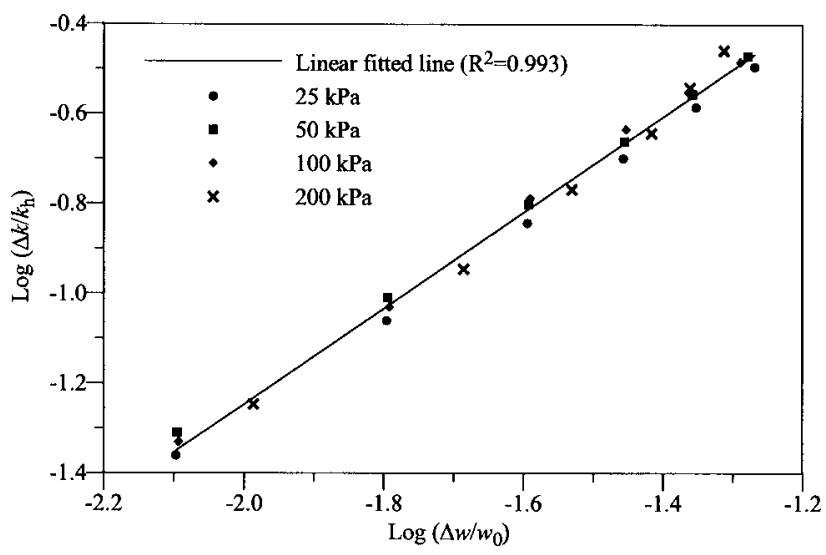

Fig. 7. Correlation between the reduction of permeability and the water content within the smear zone

\section{Correlation between Permeability and Water Content within Smear Zone}

A correlation between the permeability reduction (i.e., difference between the undisturbed and smear zone values) and water content reduction is shown in Fig. 7. This relationship is almost perfectly linear $\left(R^{2}>0.99\right)$, and the following empirical expression can be proposed

$$
\frac{\Delta k}{k_{h}}=C\left(\frac{\Delta w}{w_{0}}\right)^{n}
$$

where $k_{h}=$ permeability of undisturbed zone; $\Delta k=$ permeability reduction; $w_{0}=$ water content of undisturbed zone; and $\Delta w=$ reduction in water content $\left(\Delta w=w_{0}-w\right)$. The empirical coefficients $C$ and $n$ are 8.32 and 1.1, respectively, for the current test results.

The above equation can be very useful in practice, because by measuring the water content variation, the associated horizontal permeability may be estimated. Since Indraratna and Redana (1998) have used same clay for their study, the above-proposed solution can be applied to back-calculate the smear zone permeability using the same empirical coefficients $(C=8.32, n=1.1)$. For example, the following data have been extracted from Indraratna and Redana (1998) for an applied pressure of $32.5 \mathrm{kPa}$. The void ratio $(e)$ and permeability $\left(k_{h}\right)$ in the undisturbed zone were 1.025 and $2.75 \times 10^{-10} \mathrm{~m} / \mathrm{s}$, respectively, and the value of $e$ at a radial distance of $50 \mathrm{~mm}$ inside the smear zone was 0.965 .

Since the water content is directly proportional to the void ratio at full saturation $(w=e / G)$, Eq. (1) can be rewritten in terms of void ratio reduction as

$$
\Delta k=C k_{h}\left(\frac{\Delta e}{e_{0}}\right)^{n}
$$

Now substituting, $\quad e_{0}=1.025, \quad k_{h}=2.75 \times 10^{-10} \mathrm{~m} / \mathrm{s}$, $\Delta e=1.025-0.965=0.06, C=8.32$, and $n=1.1$ into Eq. (2): $\Delta k=1.0083 \times 10^{-10} \mathrm{~m} / \mathrm{s}$. Therefore the permeability at the selected point is $1.7416 \times 10^{-10} \mathrm{~m} / \mathrm{s}$, which is the same as the measured value of $1.74 \times 10^{-10} \mathrm{~m} / \mathrm{s}$.

\section{Conclusions}

The characteristics of the smear zone created by mandrel driven prefabricated vertical drains were investigated using a large-scale consolidometer. The extent of the smear zone can be explained on the basis of either the variation of permeability anisotropy $\left(k_{h} / k_{v}\right.$ ratio), or normalized permeability $\left(k_{h} / k_{h u}\right.$ ratio), or the change in water content. In all these methods, the extent of the smear zone for Moruya clay was found to be about 2.5 times the equivalent mandrel radius. However, the size of the smear zone may vary depending on the dimensions (shape) of the mandrel, the speed of installation, and the soil stiffness. An expression between the change in water content and the change in horizontal permeability within the smear zone is found, and this empirical expression is very useful in a practical sense for estimating the lateral smear zone permeability by measuring the water content.

\section{References}

Babu, G. L. S., Pandian, N. S., and Nagaraj, T. S. (1993). "A reexamination of the permeability index of clays." Can. Geotech. J., 30, 187-191.

Barron, R. A. (1948). "Consolidation of fine-grained soils by drain wells." Trans. Am. Soc. Civ. Eng., 113, 718-724.

Hansbo, S. (1981). "Consolidation of fine-grained soils by prefabricated drains." Proc., 10th Int. Conf. SMFE, Stockholm, Vol. 3, 677-682.

Indraratna, B., and Redana, I. W. (1997). "Plane strain modeling of smear effects associated with vertical drains." J. Geotech. Geoenviron. Eng., 123(5), 474-478.

Indraratna, B., and Redana, I. W. (1998). "Laboratory determination of smear zone due to vertical drain installation." J. Geotech. Geoenviron. Eng., 124(2), 180-184.

Samarasinghe, A. M., Huang, Y. H., and Drnevich, V. P. (1982). "Permeability and consolidation of normally consolidated soils." J. Geotech. Eng. Div., Am. Soc. Civ. Eng., 108, 835-840.

Tavenas, F., Jean, P., Leblond, P., and Leroueil, S. (1983a). "The permeability of natural soft clays, Part I: Methods of laboratory permeability measurement." Can. Geotech. J., 20, 629-644.

Tavenas, F., Jean, P., Leblond, P., and Leroueil, S. (1983b). "The permeability of natural soft clays, Part II: Permeability characteristics." Can. Geotech. J., 20, 645-660.

Taylor, D. W. (1948). Fundamentals of soil mechanics, Wiley, New York, 700. 